\title{
Sexualidade e corpo: o olhar do sujeito através das imagens em vídeo
}

\author{
Sexuality and the human body: \\ the subject's view through video images
}

Eliane Portes Vargas 1

Vera Helena Ferraz de Si queira 2

\footnotetext{
1 Centro de Saúde-Escola Germano Sinval Farias, Escola Nacional de Saúde Pública, Fundação Oswaldo Cruz. Rua Leopoldo Bulhões, 1480, Ri o de Janeiro, RJ 21045-900, Brasil. epvargas@openlink.com.br 2 Núcleo de Tecnologia Educacional para a Saúde, Centro de Ciências da Saúde, Universi dade Federal do Rio de Janeiro. helena.siqueira@imagelink. com.br
}

Abstract This study analyzes images of the body linked to sexual and reproductive behavior found in the communication processes mediated by so-called educational videos. In the relationship between subject and technology, the paper is intended to characterize the discourses and the view or perspective currently shaping health education practices. Focusing on the potential in the relationship between the enunciator and subjects represented in the text and the interaction between health professional s and messages, the study attempts to characterize the discourses and questions providing the basis for a given view of the body and sexuality. The study was conducted in the years 1996-1997 and focused on health professionals from the public heal th system. The results show a con cept of sexuality that tends to generalize the meaning ascribed to sexual experience, ignoring the various ways by which different culturally defined groups attributemeaning to the body.

Key words Health Education; Educational Technology; Audiovisual Aids; Sex Behavior

Resumo Del imitado em torno de questões que mantém relações com práticas educati vas em saúde, este estudo tem como perspectiva de análise as imagens do corpo vinculadas ao comportamento sexual e reprodutivo nos processos de comunicação mediados pel os chamados vídeos educativos. Busca-se caracterizar, na relação do sujei to com a tecnol ogia, os discursose a di reção do olhar que conformam na atualidade tais práticas. Com especial interesse nas possibilidades de relações que o ví deo apresenta entre suj ei tos enunciador e representado que compõem o texto e profissionais de saú de nas interações com as mensagens, procura-se caracterizar os discursose questões que conformam a base de uma determinada visão do corpo e da sexualidade. O desenho do estudo teve como suj ei to profissi onais de saúde da rede pública do Rio de Janeiro no período de 1996-1997. Os resultados mostram uma concepção de sexuali dade que tende a gene rali zar o significado da experiênci a sexual, ignorando as variações entre diferentes grupos, culturalmente definidos, na atribuição de significados ao corpo.

Palavras-chave Educação em Saúde; Tecnologia Educacional; Recursos Audiovisuais; Comportamento Sexual 
Introdução

As reflexões aqui desenvolvidas têm origem em um trabalho anterior (Vargas, 1998) cuja análise estrutura-se em torno de dois eixos: as imagens do corpo produzidas em vídeo, no que concerne às representações do corpo e da sexualidade e suas relações com o discurso de profissionais de saúde na interação com as imagens em práticas de educação no campo da saúde.

Neste artigo, busca-se contemplar o significado atribuído às dimensões sexuais e reprodutivas do corpo, na ótica de profissionais de saúde, mediado pelos chamados vídeos educativos. Tem-se como propósito indicar o contexto que informa e oferece as possibilidades de rel ações que o vídeo apresenta entre sujeitos enunciador e representado, que compõem o texto - e profissionais de saúde em suas ações, com base em uma reflexão sobre o processo social de recepção de mensagens através de imagens, em contexto educativo. Ao buscar compreender a relação dos sujeitos com a tecnologia, pretende-se uma caracterização dos discursos sociais em termos das representações e dos valores modeladores do ol har e da percepção do sujeito sobre as imagens produzidas. Assim, o universo desse estudo encontrase circunscrito às representações do corpo e da sexualidade, emergentes no atual contexto das abordagens educativas no campo da saúde e presentes nas imagens em vídeo, que se ligam a determinadas práticas sociais e significados, modeladores da construção de gênero, da experiência da sexualidade e da reprodução.

O universo do estudo abrange parte de uma produção em vídeo que se alinha, direta ou indiretamente, às formulações e reivindicações mais recentes oriundas dos movimentos sociais pela saúde, emergentes principalmente na década de 80 . Esses movimentos, que se convencionou chamar gay, étnico, mulheres etc. - grosso modo e guardando suas devidas especificidades -, tentam ampliar a visão da abordagem das questões de saúde, historicamente 'naturalizadas' e tratadas de um ponto de vista biomédico. Apontam, assim, para seus condicionantes e determinantes sociais, em especial as questões culturais implicadas na constituição das identidades sociais. Tomando esse tipo de produção preferencialmente nesta investigação, tem-se como pressuposto que a utilização e difusão dos vídeos compõem as estratégias de ampliação desses movimentos, alcançando o interior das práticas nos serviços de saúde.

Pretendemos ater-nos no presente artigo ao delineamento de al guns aspectos modela- dores da percepção dos profissionais e dinamizadores dos discursos sobre o corpo, destacando o que emerge como relevante nas concepções que apóiam a abordagem da sexualidade e das relações entre os gêneros. Privilegia-se a atribuição de sentidos aos eventos relacionados ao corpo e a construção do significado como uma relação social, enfatizando-se a dimensão valorativa dos fenômenos sob observação. A opção de análise, centrada na relação do sujeito com a tecnologia e com ênfase na verificação do sentido, pauta-se na compreensão de ser a significação do corpo ligada à sexualidade uma questão central na constituição dos sujeitos e das identidades sociais na modernidade (Costa, 1996; Heilborn, 1996). O objeto dessa investigação insere-se, portanto, numa problemática situada no interior das ciências sociais, encontrando-se circunscrito à identificação dos discursos, expressos pelos sujeitos, que informam na atualidade práticas voltadas à promoção do comportamento preventivo, à ação educativa e à conscientização dos direitos sociais.

\section{Contextualização do objeto}

O desenvolvimento de recursos educativos alternativos visando à intervenção nos campos da saúde e da educação relacionada às doenças sexual mente transmissíveis (DST)/ AI DS e uso indevido de drogas (Monteiro et al., 1994) indica a importância da avaliação dos fundamentos e impacto dos usos de materiais no campo educativo, reafirmando a necessária consolidação de linhas de pesquisas e investigação sobre a produção e avaliação dos recursos articuladas à formação de recursos humanos. No que se refere ao uso do vídeo, atestase, por parte do profissional de saúde, a existência de uma demanda explícita por vídeos que abordem determinadas temáticas e questões contempladas em seu trabalho educativo. O que se denomina análise de demandas, no setor saúde, encontra-se tradicionalmente apoiado em modelos de avaliação das ações e programas onde prevalece a utilização de indicadores econômicos, tecnológi cos e de qualidade dos serviços prestados à população, com vistas à verificação de acesso, cobertura, utilização, eficácia, satisfação do usuário, objetivos, processos e resultados das ações. A importância desses indicadores no campo da saúde coletiva é hoje amplamente reconhecida, assim como seus limites (Deslandes, 1997; Silver, 1992). Promover uma escuta mais atenta e exercitar aidentificação de questões que estejam mais próximas 
das necessidades e dos valores da clientela-alvo dessas práticas faz-se necessário. Ressalta-se a quase inexistência de estudos que avaliem a recepção de mensagens produzidas em vídeo.

Quanto ao universo do vídeo, este caracteriza-se por uma essencial heterogeneidade e, enquanto fenômeno da imagem eletrônica, é múltiplo, variável, instável e complexo (Machado, 1996). Depara-se ainda com uma imprecisão conceitual do termo "vídeo educativo" que se encontra pouco problematizado do ponto de vista teórico. Não se pretende, no entanto, centralizar a discussão sobre a caracterização da especificidade do que se convencionou chamar vídeo educativo, mas, sim, indicar o contexto de produção, destacando seu caráter educativo, que comumente o identifica e o distingue. Cabe ressaltar que é precisamente o caráter de intervenção, característico das práticas e ações de saúde configuradas pelos movimentos pela melhoria da saúde, que enquadra a produção em questão como sendo de caráter educativo. Deve-se considerar, no entanto, a necessidade de identificar elementos que dêem alguma coerência a esse universo aparentemente caótico. Assim, o olhar sobre as imagens volta-se para a exposi ção de algumas características que identificam um conjunto específico de produção. As informações colhidas de levantamento quantitativo realizado em acervos de bibliotecas (institucionais e ONGs), catálogos, folders informativos e entrevistas com profissionais de serviços de saúde permitem compor um quadro da produção dos vídeos educativos em termos de suas características mais gerais quanto à temática, ao público e ao gênero de produção. Contudo, tal caracterização não se torna suficiente ao delineamento dos contornos de utilização da produção em vídeos, pois deixa à margem alguns elementos fundamentais do processo comunicativo e inerente ao trabal ho educativo. Um dos elementos que constitui em particular interesse é a interação do sujeito com as mensagens educativas, apreendida a partir da interpretação feita pel os profissionais de saúde sobre as imagens produzidas em vídeo. Considera-se ser inerente a esse processo, com as características recortadas, a inscrição no discurso dos profissionais das dimensões sexuais e reprodutivas do corpo por sua vez modeladas por determinadas concepções e representações acerca da saúde, do corpo e da sexualidade. Tem-se como perspectiva que, na interação com as mensagens e no processo de identificação (Borges, 1996:135) dos sujeitos, concorrem inserção social, pertencimento cultural e valores morais expressos subjetivamente nas questões problematizadas pelo coordenador ao proceder à leitura ou utilizar o vídeo com determinada intencionalidade educativa.

A imagem tem se mostrado como uma linguagem poderosa no campo da comunicação, cujo desafio consiste em conhecer seu potencial nos processos e nas práticas de caráter educativo. Por tratar-se de vídeos, há ainda uma característica particular, qual seja a imagem em movimento, que Ihe confere um estatuto específico nesse campo de produção. Não obstante o reconhecimento dessa especificidade, tem-se como propósito destacar, nesse conceito, sua função de representação da realidade como um dos aspectos privilegiados na análise dos fenômenos em comunicação. Aumont (1993) considera a imagem como mediadora de representações e propõe que "toda representação é rel acionada por seu espectador - ou me Ihor, por seus espectadores históricos esucessivos - a enunciados i deológicos, culturais, em todo caso simbólicos, sem os quais ela não tem senti do" (1993:248). Sua importância analítica encontra-se, portanto, nas relações essenciais que mantém com o objeto de investigação em termos de sua vinculação com o domínio do simbólico, o que confere à imagem uma posição de mediadora entre espectador e realidade.

Essa opção teórica metodológica impõe que sejam contempladas questões até então não devidamente desenvolvidas em anál ises de vídeos com finalidade educativa, sabidamente escassas, como apontado por Siqueira (1998). Uma delas diz respeito à necessidade de pôr em evidência o contexto de produção valendose da construção histórica dos discursos sobre o corpo e a sexualidade, que não só informam a esfera de produção (incluem-se aqui produtores e usuários de recursos educativos), como também extrapolam a experiência imediata dos sujeitos envolvidos nas ações educativas. Outra questão diz respeito ao desenvolvimento de um aporte teórico-metodológico que dê sustentação às análises dos fenômenos culturais como mediação necessária à comunicação em saúde, a fim de oferecer subsídios à avaliação do uso de recursos educativos preventivos, uma vez que tal uso encontra seus limites em uma visão instrumental dos processos de educação e de comunicação que se impõe no cotidiano das práticas, na abordagem de seus conteúdos e, conseqüentemente, na utilização dos vídeos e na avaliação de seus resultados. Assim, o objeto insere-se também numa problemática ampla circunscrita ao debate atual dos modelos de educação e de comunicação que informam o comportamento e as intervenções no campo das ações preventivas e assistenciais 
em saú de (Pitta \& Meira, 1990; Abrasco, 1992; Schall \& Struchiner, 1995).

Isto posto, cabe ressaltar que não se pretende aqui analisar ou esboçar propostas de modelos de intervenção ou alcançar respostas conclusivas, mas, antes, buscar outros ângulos de visão que contribuam e somem esforços na superação dos dilemas colocados às intervenções educativas em saú de na atualidade. É pertinente reconhecer que as questões pontuadas oferecem o apoio necessário à opção por um determinado tipo de interpretação, dentre outras, que se pretende realizar sobre as imagens em vídeo. O esforço empreendido se faz no sentido de enfatizar, no processo comunicativo - mediado pelo vídeo educativo - , a importância de serem contempladas, em grupos culturalmente definidos, as representações e valores modeladores da subjetividade, que posicionam o sujeito na estrutura social. No âmbito das políticas públicas e ações educativas/comunicativas, dilemas e impasses têm-se apresentado mediante as atitudes aparentemente contraditórias de homens e mulheres em termos do comportamento sexual e reprodutivo na prevenção e proteção contra o vírus HIV (Barbosa \& Villela, 1994). Nessa direção particularmente rica, tem sido a contribuição antropológica na análise dos comportamentos dos sujeitos impulsionado pela AIDS (Guimarães, 1994a, 1994b, 1996; Knauth, 1995, 1996, 1998), onde o tema da sexualidade emerge como central pelas próprias características de transmissão da doença e de configuração da epidemia. Esses estudos sobre o contexto cultural que agencia a vulnerabilidade feminina mediante a epidemia, ao revelarem a existência de uma lógica cultural específica regida por valores morais, tentam explicar a aparente contradição identificada no comportamento não preventivo dos sujeitos sociais, em situações comprovadas, on de os mesmos não se encontram totalmente desinformados sobre a doença. O que se tenta afirmar nesses estudos é a positividade da cultura do segmento popular, o que implica poder olhá-lo por uma ótica diferente da que o remete à "i gnorância” ou à "falta de informação" (Leal, 1995a), ótica esta, embora exaustivamente denunciada, ainda bastante prevalente. A análise sobre o sentido da proteção em jovens de camadas populares (Monteiro, 1999) indica a necessidade de incorporação das representações sociais, presentes na percepção desse grupo, nas estratégi as preventivas propostas para o enfrentamento da epidemia. Oferece ao debate, no campo preventivo, uma interessante contribuição ao destacar as percepções e as práticas de proteção dos jo- vens relacionadas à doença. Esses estudos mais uma vez colocam em evidência a AIDS como um dos maiores problemas a ser enfrentado na atualidade em termos de políticas públicas e também como propiciadora de debates relacionados aos sentidos do corpo, à sexualidade e às identidades sexuais. No que se refere a um recorte analítico mais amplo, afinado com as vertentes mais tradicionais dos estudos antropológi cos sobre a 'construção' da Pessoa e do Corpo, podem-se identificar vários investimentos em análises dos fenômenos pautados na experiência da doença, do sofrimento e do malestar designados, na cultura ocidental moderna, como doença e saúde (Duarte \& Leal, 1998).

As práticas que compõem o conjunto de ações em saúde de caráter educativo, quando analisadas historicamente, revelam a presença do projeto hegemônico da medicina nas práticas de saúde. Constitui-se, portanto, como um conjunto de práticas autoritárias, normalizadoras e disciplinadoras de condutas, ficando o corpo, tomado como "indivíduo bi ológico", subordinado às ações médicas (Oshiro, 1988:1018). Borges (1996), problematizando os limites das intervenções educativas, tendo como base o campo da psicanálise, chama a atenção para o mal-estar no trabalho de educação em saúde. Este se expressa pelo desconforto gerado naqueles que se ocupam da tarefa de educar quando deparam, como no dizer da autora, com "corpos rebel des" e insu bordinados em relação às orientações educativas preventivas (Borges, 1996:20-35). Outros estudos indicam ainda os limites das intervenções pautadas apenas na informação e na responsabilidade individual e/ ou ressaltam a existência de problemas de comunicação entre os atores envolvidos nessas ações (Oshiro, 1988; Pamplona, 1990; Vieira, 1990; Assis, 1992; Melo, 1993; Pereira, 1993; Chatel, 1995; Leal, 1995a, 1995b; Heilborn \& Gouveia, 1997).

Assim, parte das motivações presentes nessa investigação encontra-se na necessidade de desenvolver uma reflexão que vá além do reconhecimento de que tanto as práticas, quanto as produções em vídeo, constituem-se em estratégi as de sensi bilização para uma abordagem mais atualizada e menos 'naturalizada' dos temas de saúde. Reconhece-se que a produção em vídeo caracteriza-se por seu caráter estratégico de ampliação do debate das questões de saúde para o conjunto da sociedade. Pretende também, dessa forma, influir nas políticas públicas e alcançar a rede de serviços visando reconfigurar modelos assistenciais mais afinados com o que se considera demandas e necessidades de saúde. No entanto, não se pretende per- 
der de vista que temas e conteúdos, mesmo os mais progressistas e consi derados necessários para a mudança do comportamento preventivo, são determinados historicamente. Além disso, sua abordagem encontra-se sob forte influência do modelo biomédico hegemônico ainda prevalente em grande parte das análises e intervenções no campo da saúde. Parece persistir ainda a idéia de serem os eventos relacionados ao corpo, entre os quais se inclui a reprodução humana, considerados como um processo eminentemente biológico ou natural que se efetiva de modo externo às relações sociais (Loyola, 1992:94). Tem-se como propósito, considerando tratar-se de profissionais de saúde que funcionam como mediadores das práticas relacionadas à clientela dos serviços de saúde, não só reafirmar o uso de vídeos como recurso de comunicação nos processos educativos, mas também interrogar seu potencial e seu real aproveitamento enquanto meio facilitador para o alcance dos sujeitos a quem se destinam as mensagens educativas.

O processo de investigação: algumas considerações metodológicas

Alguns pontos, que dizem respeito às opções teórico-metodológicas adotadas, devem ser considerados como intrínsecos à metodologia utilizada. Em primeiro lugar, vale dizer que tais opções estão determinadas por questões internas relativas tanto ao quadro teórico de referência, quanto ao contexto social e as condições institucionais que em seu conjunto influenciaram o direcionamento teórico e prático da pesquisa.

Buscando suprir as necessidades decorrentes do tipo de análise proposto, contou-se com o aporte teórico e a contribuição de diversas áreas do conhecimento. Assim, este estudo pôde ser beneficiado por reflexões teóricas oriundas de campos diversos, como o das teorias da recepção, metodologias de avaliação da recepção de mensagens e dos estudos cinematográficos constituídos com base na experiência do cinema. Como não poderia deixar de ser mencionado, beneficiou-se também das reflexões e contribuições do pensamento freudiano, embora não esteja aqui proposto tratar teoricamente as questões valendo-se de conceitos do campo da psicanálise. Pode-se, assim, percorrer um caminho conceitual que possibilita um deslocamento do olhar da produção para a esfera da recepção de mensagens, concebida também como um núcleo de significação, e então descrever o que este pólo faz com o que é produzido por um outro. No entanto, nesse percurso, apresentam-se alguns dilemas que devem ser explicitados por serem compreendidos como parte do processo de reflexão teórico-metodológico no sentido indicado por Lopes (1994), em análise de modelos metodológicos de pesquisa em comunicação. Dessa forma, depara-se com uma questão que diz respeito ao como levantar, tendo como base o quadro de referência adotado, os dados empíricos no que concerne aos discursos sobre o corpo na abordagem da sexualidade, como um fenômeno de comunicação mediado pelo vídeo educativo. Tal questão refere-se, também, ao como descrever esse processo, ciente da insuficiência de publicação de textos voltados à metodologia no campo da comunicação (Lopes, 1994), confirmada em revisão bibliográfica específica sobre vídeo. Siqueira (1998) compartilha dessa opinião indicando que muito pouco se tem investigado em relação a materiais educativos, dentre os quais se incluem os vídeos e sua utilização no campo da saúde. A análise deste autor está voltada para a identificação da construção da intencionalidade pedagógi ca dos vídeos educativos e para um contexto de produção ligado em sua gênese ao ensino superior. Já Langenbach (1993) reflete sobre algumas modalidades do uso do vídeo como recurso de sensibilização no contexto escolar, apontando para a necessidade de se repensar e reestruturar o processo educacional com ênfase na construção coletiva do saber. Podem-se relacionar ainda outros trabalhos, entre teses e artigos, com características e recortes específicos na abordagem do vídeo como meio de comunicação. Alguns textos, como os da FASE (FASE, 1989) e de Ceccon (1989), indicam uma tendência na produção e utilização do vídeo como instrumento de comunicação popular e de intervenção educativa visando à reflexão e à ação numa perspectiva de educação popular. Nestes artigos, os trabalhos da FASE e do CECIP (Centro de Imagem de Criação Popular) são indicados como sendo a base da experiência na abordagem do vídeo popular. Romano (1990) propõe-se a estabelecer as relações entre o vídeo popular e o contexto político e ideológico dos movimentos sociais (toma como exemplo os movimentos sindicais, movimento de mulheres, de associação de moradores etc.). Já em Melo (1993), encontramos o uso do vídeo especificamente por grupos feministas como um meio de apoio às suas ações comunicativas da realidade social e como uma sistematização das informações dispersas sobre a temática da mulher. Numa perspectiva antropológica, Paula (1996) reflete sobre o uso 
do vídeo na construção social da identidade cultural, através do qual os discursos sobre o mundo indígena e não indígena são reproduzidos. Pôde-se, ainda, ter acesso a um projeto de avaliação do vídeo educativo (Rozemberg, 1995a, 1995b) produzido para - e com a participação de - moradores de área endêmica de esquistossomose no campo da saúde. A diversidade de enfoques e problematizações encontradas possibilitou entrever a existência de extensa variedade de aplicações e recortes teóricos sobre o vídeo. Portanto, procurou-se identificar os elementos teóricos e as estratégias metodológicas que melhor pudessem oferecer alguma coerência à análise, visto que, sobre a temática do corpo e da sexualidade relacionada ao vídeo, com ênfase na recepção de mensagens, não se encontrou nenhum estudo.

Assim, a presente análise voltou-se à compreensão dos modos como os vídeos são consumidos por determinado grupo social, não apenas baseando-se em seus conteúdos, mas também valendo-se da caracterização das condições sociais de produção e consumo dos chamados produtos culturais. Nesse sentido, pauta-se na idéia de consumo como também como espaço de produção de sentido (Lopes, 1994:56). Seguindo na direção dessa caracterização, uma classificação dos vídeos por segmentos da população ou público específico para o qual estariam direcionadas tais mensagens pode ser encontrada nas sinopses dos conteúdos e dos títulos, ambos indicando as temáticas abordadas e o público-alvo. No entanto, constitui-se um problema teórico-conceitual, que deve ser enfrentado em análises posteriores, o fato de se pensar a recepção das mensagens em vídeos educativos por um grupo social a que se denomina, genericamente, clientela dos serviços públicos de saúde ou segmento populacional definido a partir das ações de saúde. Isso determinou a opção pelo profissional de saúde como informante privilegiado do estudo, pois, em se tratando de vídeos, depara-se com um mediador fundamental, que elege o recurso para o desenvolvimento de suas ações educativas e proporciona o acesso necessário ao vídeo junto à clientela.

Sendo assim, ainda estamos instalados no pólo da produção, considerando que profissionais de saúde, através de suas práticas, são também componentes dos segmentos sóciopolítico-institucional, formuladores dos discursos e das concepções predominantes sobre o corpo na abordagem da sexualidade. Não estamos considerando a veiculação de vídeos via satélite, o que teoricamente conferiria maior autonomia da recepção, mas sim a utilização restrita no âmbito dos serviços de saúde. Detivemo-nos, dessa forma, em aprofundar como esses profissionais lidam com os discursos revelados pelas imagens, indicando os pontos de contato e mediações de sua ação junto à clientela. Através das estratégias metodológicas adotadas, tentou-se abranger um número maior (e possível) de ângulos de visão que permitissem efetuar o recorte necessário aos propósitos do estudo.

\section{Material e método}

Em se tratando de pesquisa qualitativa que tem como universo empírico as imagens em vídeo e o discurso dos profissionais de saúde, o estudo incluiu: levantamento e classificação dos vídeos disponíveis; observação participante; realização de grupos de discussão e entrevistas no período de junho a setembro de 1996. O trabaIho de campo foi feito em dois postos de saúde (zonas norte e sul do Rio de Janeiro) e no Centro deTreinamento da Secretaria Municipal de Saúde (SMS) do Rio de Janeiro (RJ ). Compuseram a amostra nove profissionais (três enfermeiras, uma psicóloga, duas assistentes sociais, duas nutricionistas e uma auxiliar de enfermagem), todas do sexo feminino, que desenvolvem atividades educativas e assistenciais voltadas à clientela nos serviços públicos de saúde. Parte desse grupo tem como função principal atividades cujo objetivo é a formação de equipes multiprofissionais nos cursos oferecidos pela SMS/RJ. Pretendeu-se a inclusão de profissionais com esses dois tipos de atribuições na amostra. Assim como a inserção efetiva do profissional em atividades educativas, a disponibilidade e o interesse em participar do trabalho de campo.

\section{Levantamento dos vídeos}

Um banco de dados das imagens (sessenta títulos) produzidas nas décadas de 80 e 90 foi organizado a fim de oferecer um conjunto de informações que comporiam o universo pesquisado. Como parte dessa atividade, procedeu-se a uma leitura de todos os títulos vistos e ordenados, com o auxílio dos catálogos das bibliotecas, com referência a: produção, realização, direção, duração, público-alvo, gênero (documentário/ficcional), ano de produção, participação em mostras, prêmios recebidos e sinopse do material produzido. Por vezes, observouse uma não-distinção em relação a produtores e realizadores, o que pode ser atribuído à espe- 
cificidade do campo desse tipo de produção. A estruturação desse banco foi resultado de levantamento realizado em três bibliotecas que possuem acervo de vídeo e em catál ogos de organ izações governamentais e ONGs disponibilizados para consulta, respectivamente: Biblioteca Central/ Fundação Oswaldo Cruz e Biblioteca da Escola Nacional de Saúde Pública/ Fundação Oswaldo Cruz - ambas vinculadas ao Departamento de Comunicação e Saúde/ Centro de Informação em Ciência e Tecnologia/ Fundação Oswaldo Cruz (ex-Núcleo deVídeos); Biblioteca do NUTES/ U FRJ (Núcleo de Tecnologia Educacional para a Saúde/Universidade Federal do Rio de Janeiro); ABIA (Associação Brasileira Interdisciplinar de AIDS); CNDM (Conselho Nacional de Direitos da Mulher); ECOS (Estudos e Comunicação em Sexualidade Humana); IBASE (Instituto Brasileiro de Análises Sociais e Econômicas); REDEH/CEMINA (Rede de Defesa da Espécie Humana) e SOS Corpo/Recife (SOS Corpo, Gênero e Cidadania). A seleção dos exemplares que comporiam a amostra foi realizada observando-se alguns critérios, a saber: a variedade de temas de saúde que se relacionam direta ou indiretamente à sexualidade, como os vídeos voltados, por exemplo, à contracepção, à gestação, às DST/ AIDS etc.; a diversidade de público-alvo a quem o material se destina, como adolescentes, educadores, mulheres etc.; e participação e prêmios recebidos em mostras de vídeo. A título de ilustração, pode-se indicar, como resultado mais geral da atividade de levantamento dos vídeos, a caracterização dos seguintes temas contemplados pel os exemplares: AIDS (abordagem da morte associada à AIDS; sensibilização de profissionais de saúde; impacto da epidemia nos jovens; prostituição; mulheres na relação com parceiros; a descoberta da sorologia positiva; sexualidade; homossexualidade; trabalho comunitário; possibilidade de cura; o risco de contaminação para as mulheres; meninos de rua; tabus e formas de contágio); parteiras; o interesse sexual na idade madura; aborto; relações de gênero; casamento; sexualidade feminina; sexualidade na adolescência; sexualidade e reprodução; questão populacional; contracepção; drogas; movimento feminista; prática educativa; prostituição; contracepção e gravidez; laqueadura tubária; geração de renda; assistência perinatal e pré-natal; parto; condição feminina; DST; educação sexual nas escolas; novas tecnologias reprodutivas. As informações reunidas sobre o acervo foram disponibilizadas para o Banco de Materiais Educativos organizado pelo LEAS (Laboratório de Educação Ambiental em Saúde, De- partamento de Biologia/ Instituto Oswaldo Cruz/ Fundação Oswaldo Cruz), cujo objetivo consiste na organização, divulgação e desenvolvimento de linhas de investigação sobre esse tipo de produção no campo educativo preventivo. Quanto ao público, em sua maioria, dirigem-se a três grupos: a adolescentes, mulheres, população em geral. Embora os vídeos abordem a sexualidade e temáticas afins, destaca-se um único exemplar dirigido aos homens, com ênfase na homossexualidade masculina. Logo, essa produção estrutura-se com a ausência de representação do masculino.

\section{Realização de grupos de discussão}

Três vídeos (Julieta e Romeu - ECOS, 1996; Uma Vezinha Só - ECOS, 1996; Entre Quatro Paredes - ABIA/TV ZERO, 1995) que fazem parte do universo da pesquisa foram exibidos aos profissionais e assim se caracterizam: 1) Quanto ao gênero: dois ficcionais (Julieta eRomeu e Uma Vezinha Só) e um documentário (Entre Quatro Paredes), sendo o primeiro dos ficcionais premiado em mostra de vídeos. 2) Quanto ao tema: abordam contracepção, gravidez na adolescência, negociação do uso do preservativo, aborto e sexualidade. 3) Quanto ao alvo: público em geral, adolescentes e mulheres. Pretendeu-se diversificar o enfoque e a forma utilizada na abordagem dos temas. Foram realizados cinco grupos, compostos por profissionais de uma mesma unidade de saúde e mistos. A discussão levantou aspectos relacionados aos conteúdos e formas, adequação público/mensagem, impressões gerais causadas pelas imagens e cenas mobilizadoras, bem como a temática predominante e o que esteve ausente na abordagem.

\section{Observação participante}

Realizada em dois contextos: o primeiro em uma unidade de saúde da zona sul com profissionais que utilizam vídeos em suas dinâmicas; os grupos contaram, em média, com 15 mulheres pertencentes ao segmento popular; o segundo em um curso para 21 auxiliares de enfermagem da rede pública. Obteve-se um total de oito observações de atividades coordenadas pelos profissionais de saúde, com duração média de quatro horas cada uma. 


\section{Entrevistas}

Semi-estruturadas com profssionais de saúde da rede pública que utilizam vídeos em suas atividades.

Cabe, por fim, ressaltar que, embora o estudo tenha tido essa abrangência, no presente artigo não estaremos analisando a totalidade das informações geradas pela investigação. Uma análise mais compl eta dos dados reunidos encontra-se descrita no trabalho de Vargas (1998), anteriormente citado.

\section{Perspectivas de análise}

Em termos conceituais, tanto a imagem, quanto o ol har do sujeito sobre o vídeo educativo, interesse específico deste artigo, são vistos na ótica antropológica, sociológica e de alguns estudos apoiados na teoria psicanalítica, conforme já indicado. Os conceitos de corpo, gênero, sexualidade, identidade social e imagem apóiam a análise das relações entre o contexto da produção videográfica à realidade social objetiva/ aspectos subjetivos, culturais e simbólicos que vinculam-se à clientela/público receptor que se encontram presentes na interpretação dos profissionais de saúde.

Em se tratando das imagens do corpo, no que concerne ao comportamento sexual e reprodutivo, a indicação dos discursos prevalentes na abordagem da sexualidade constitui-se em uma dimensão teórica importante, onde se destaca o corpo como construção social (Boltanski, 1979) e simbólica, e não somente como biológico. Busca-se relativizar as categorias que apóiam a construção dos discursos, na explicação dos eventos que se ligam ao corpo no interior de sistemas culturais particulares, haja visto a atribuição de valor dada a esses eventos através das classificações dicotômicas de comportamentos e atitudes segundo os sexos observada em toda sociedade (Héritier, 1978; Duarte, 1986; Heilborn, 1993; Bourdieu, 1995). Dessa forma, assinala-se a existência de diferentes lógicas ordenadoras das representações, expressas nos discursos, que fundam as concepções sobre sexual idade, identidade, comportamento sexual e demais categorias que historicamente procuram explicar os eventos relacionados ao corpo sexuado. Isso implica proceder-se a uma relativização da idéia de sexo para se discutir a questão da sexualidade, que decorre do reconhecimento da inexistência de um referente maior ou exclusivo dessa (Costa, 1996). Nesse sentido, a sexualidade é compreendida como uma construção social baseada nas diferenças fundamentais entre os sexos com base em uma abordagem não essencialista. A palavra sexo, nesse enfoque, passa a designar a caracterização anátomo-fisiológica dos seres humanos com vistas à desconstrução do mito da essência sexual, base da experiência ou da concepção de sexualidade modernas.

Apoiada numa concepção de identidade social construída por um "conjunto de marcas soci ais que posicionam um sujeito em um determinado mundo social", Heilborn (1996) define-a como "a moldura possível onde os sujeitos podem existir e se expressar". Postula ainda que a "modelação da pessoa" comporta simultaneamente três dimensões: a primeira delas diz respeito aos atributos e traços que constituem classificatoriamente o sujeito (indicadores de estratificação social, idade, gênero etc.); a segunda, ao modo como esses atributos inseremse no campo das significações sociais, e, por último, uma terceira dimensão seria a expressão de tais marcas mediante determinados valores que tomam corpo em significados que articulam a imagem de si e a relação com o outro (Heilborn, 1996:137). Destaca que esse processo é simultaneamente exterior ao sujeito e objeto de uma interiorização.

Quanto à definição de gênero, o conceito tem sua origem na noção de cultura que "aponta para o fato da vida social e os val ores que a organizam - como, por exemplo, tempo, espaço ou a diferença entre os sexos - são produzidos e sancionados soci al mente, através de um sistema de representações" (Heilborn, 1994: 1). Assim, o que está convencionado para a utilização do termo, enquanto categoria, éque ele possibilita uma distinção entre as dimensões anátomo-fisiológicas dos seres humanos e as dimensões culturais atribuídas a cada um dos sexos. Baseada na proposição Dumondiana (Duarte, 1986) da universalidade da hierarquia como ordenamento do mundo social, Heilborn busca as razões que expliquem a constante estrutural de assimetria na montagem das relações entre os gêneros (Heilborn, 1993, 1998).

A emergência dos discursos e as imagens do corpo

São recentes os estudos que abordam a sexualidade e as questões relacionadas à reprodução humana no campo da pesquisa social, largamente ignoradas durante a maior parte do século XX. Embora ignorada do ponto de vista da constituição das ciências sociais, a experiência da sexualidade, através dos estudos das ciên- 
cias biomédicas, esteve intimamente ligada ao corpo concebido do ponto de vista de sua existência biológica. Estudos recentes, impulsionados, em parte, pelos movimentos ocorridos no âmbito da sociedade, como desdobramentos dos movimentos sociais, a partir dos anos 60 , tentam romper com os modelos explicativos pautados na racionalidade médica, que relegaram à marginalidade as questões culturais implicadas na constituição das identidades sociais. Esse questionamento possibilitou a abertura para análises mais abrangentes dos fenômenos e questões referentes à sexualidade e reprodução, ressaltando suas dimensões políticas e sociais. Desde então, a questão dos direitos sexuais e reprodutivos têm sido amplamente debatidos.

É também recente a consolidação do vídeo, enquanto meio de produção de mensagens, como suporte de manifestações culturais e de resistência, marcado em sua origem por sua vinculação à indústria cultural e ao aparecimento de novas tecnologias no final dos anos 50. Tais man ifestações refletiam o clima político/cultural da época que incidia diretamente tanto na constituição deste campo, quanto na tônica das produções em vídeo, por influência da vinculação de seus realizadores aos movimentos sociais. Aqui se incluem os movimentos pela democratização da saúde articulados aos diversos grupos engajados nas lutas pela igualdade de direitos. Os grupos mobilizados em torno de questões e lutas específicas (de etnia, feminista, gay etc.), guardando suas particularidades, produziram uma gama de materiais e instrumentos de intervenção política, em particular no campo do vídeo. As produções, portanto, em sua gênese, mantêm relações com um contexto conjuntural mais amplo da sociedade brasileira em suas dimensões estruturais e ideol ógicas, como demonstrado por Melo (1993) em análise específica sobre a produção feminista em vídeo.

Tais tentativas, seja no campo teórico de politização das questões de saúde, seja através de iniciativas de produções independentes no campo da comunicação, com conseqüente questionamento da ordem de comunicação vigente, apresentavam-se como respostas alternativas ao saber hegemônico e à predominância das mensagens veiculadas pelos meios de massa. Assim, compreendemos que o processo de veiculação das mensagens e dos conteúdos representados por imagens através dos chamados vídeos educativos, quando anal isado à luz das atividades educativas em saúde, deve estar referido ao momento histórico de sua produção e utilização.
Os vídeos que compõem o universo desta investigação vinculam-se a um tipo de produção que encontra suas raízes na expansão dos movimentos de mulheres e do movimento homossexual masculino. Desdobrando-se nos anos 80, esses movimentos buscam legitimar culturalmente determinadas práticas e relações entre os sexos, apontando as contradições presentes no universal sistema de dominação das culturas tradicionais, em especial nas relações entre os gêneros. Também encontra suas raízes nas diversas vertentes dos movimentos alternativos e de educação popular, tornandose, sob a influência destes, instrumento político e de intervenção. Em Hollanda (1993), pode-se encontrar uma referência conceitual para se pensar sobre os pressupostos orientadores de metodologias (Valla \& Stotz, 1993) sobre participação popular.

No contexto brasileiro, no decorrer da década de 80, a partir dos marcos iniciais de luta pela igual dade de direitos sexuais e reprodutivos, programas voltados às inter venções nas questões de saúde junto às mulheres foram desenvolvidos, assim como ações e materiais educativos com o objetivo de minorar os reflexos das desigualdades sociais nas condições de saúde de homens e mulheres. Ressalta-se aqui a especificidade da participação dos setores feministas no campo da saúde, o que derivou a elaboração de propostas no campo das políticas públicas objetivando o atendimento das chamadas demandas femininas (PAISM, 1983).

Educação e comunicação: elementos para se pensar a recepção das imagens em contexto educativo

As atuais tendências das investigações no campo da comunicação social, constituídas a partir da trajetória latino-americana da pesquisa nessa área (Melo, 1985; Orozco \& Jacks, 1993; Lopes, 1994; Barbero, 1995; Leal, 1995b; Neto, 1995), indicam uma tendência à relativização da subordinação do receptor ao texto. Nesse caso, a recepção é concebida como processo mediado e o receptor é visto como sujeito da engrenagem, ativo, que age através de associações, transferências, projeções e avaliações que fazem dele um leitor detentor de uma decisão interpretativa sobre o texto que Ihe é ofertado. Dessa forma, pode-se considerar que a rel ação dos sujeitos com as imagens em vídeos é de natureza simbólica, definida pelo estoque cul tural e pela posição que cada usuário ocupa no cenário social, modeladores de sua subjetividade. 
Em se tratando de relações comunicativas sobre saúde e doença, no âmbito da prevenção, as representações do corpo humano, sejam elas hegemônicas, ou contra-hegemônicas, serão sempre produções simbólicas (Lefèvre, 1995). Supõe-se, assim, que na produção em vídeo encontra-se representado um determinado tipo de receptor das mensagens, para o qual são dirigidas as mensagens educativas, no senso comum denominado público-alvo, geralmente pertencente às camadas populares. Detendo-se nas formas através das quais as mensagens educativas expressam representações sobre a sexualidade, tenta-se pôr em evidência como o corpo em imagens - corpo da clientela, público-alvo das ações - apresentase como estrutura componente dos vídeos. Pode-se supor a existência de uma determinada visão de um outro, constituído culturalmente e posicionado na estrutura social, que se encontra expresso na construção de determinados tipos ou estereótipos. Assim, pretende-se avançar na compreensão de que o sentido não se encontra restrito ao campo da mensagem em si, em termos de seus conteúdos, mas enfeixado em relações sociais concretas.

A interação com as mensagens, considerada como relacional e produto de uma atividade interpretativa realizada pelos profissionais, distingue-se do face a face, origem de todas as formas de interação social. Ressalta-se que o processo interativo comporta uma dimensão relacional, já que origina uma imagem do outro - que é, ao mesmo tempo, imagem de si próprio, conforme Iser (1979). Ao se considerar o sujeito que olha a imagem, o espectador ou então o receptor das mensagens veiculadas em imagens, deve-se ter como parâmetro que a visão efetiva destas realiza-se em um contexto multiplamente determinado: contexto social, contexto institucional, contexto técnico, contexto ideológico (Aumont, 1993).

Os sentidos do corpo:

o olhar do sujeito sobre as imagens

As reflexões a seguir apóiam-se nas seguintes questões, implicadas no esforço de construção de parâmetros para leitura dos vídeos: os discursos em torno da constituição das identidades sociais; a significação do corpo ligado à sexualidade como central à constituição das identidades na modernidade; a emergência destas formas discursivas em práticas e materiais de natureza educativa.

Considerou-se a questão da sexualidade de difícil abordagem e, na interpretação dos pro- fissionais, emerge relacionada aos comportamentos dos personagens representados, com ênfase especial, nos tipos femininos. Foi assinalada, em uma das interações, uma certa dificuldade por parte de uma personagem feminina em falar sobre sexo, referido aqui a práticas sexuais e reprodutivas, bem como sobre assuntos considerados tabus, como: relações sexuais com alguém do mesmo sexo, a masturbação, o aborto etc.

“Na verdade é difícil fazer um vídeo sobre sexualidade..."

“Então eu queria muito um ví deo que botasse essas coi sas (...) mais claras e mais presentes no cotidiano de qualquer pessoa, seja ela assim, assado, que essas coi sas existem no cotidiano de qual quer cl asse, qualquer... E assim queria um vídeo (...) que mostrasse (...) mais lugar comum. Entendeu?"

A necessidade de se compreender o que é comum na experiência da sexualidade surge através de uma demanda por um vídeo que pudesse mostrar as experiências vivi das no cotidiano de qualquer pessoa, sugerindo a existência de uma percepção homogeneizadora da sexualidade. A acertiva de que, na cultura ocidental, a identidade sexual constituiu-se numa das dimensões centrais da identidade social das pessoas vincula-se a uma perspectiva construtivista. Nesta perspectiva, “a sexualidade não possui uma essência a ser desvelada, mas é antes um produto de aprendizado de significados socialmente disponíveis para o exercício dessa ati vidade humana" (Heilborn, 1996:137). $\mathrm{Na}$ percepção do profissionais, pode-se vislumbrar ainda uma ten dência a não enfatizar a diversidade cultural dos segmentos sociais nos quais encontram-se inseridos os sujeitos-alvo das ações comunicativas/ educativas. Uma das personagens femininas, identificada como dona de casa teria tido, na ótica dos profissionais, maior dificuldade em falar sobre sexo. Contrastada com os demais tipos femininos, a dona de casa, pertencente ao segmento popular, surge como representação daquela que "não tem intimidadeabsolutamente al gu ma com o uso da camisinha" e parece mais embaraçada para falar, em relação às demais, de assuntos relacionados a sexo. Tal compreensão tende a desconsiderar o contexto social e a coexistência de diferentes códigos culturais como em análise de Duarte (1987), que indica a existência de outras lógi cas ordenadoras das representações e valores presentes na interpretação das experiências da classe trabalhadora urbana. Cabe ressaltar aqui que se pretende afirmar as práticas es comportamentos sexuais como experiências de importância subjetiva para mulheres e ho- 
mens pertencentes aos diversos grupos, no entanto tais experiências não ganham relevância como objeto de discurso para os segmentos populares. Dito de outra forma, a sexualidade parece não se constituir em objeto específico do discurso e nem como referência básica para a definição identitária desses segmentos sociais. Antes, o sexo, para determinados grupos, emerge subsumido a uma ordem moral fami liar (Ropa \& Duarte, 1985). Na apreensão das regras que constituem a moralidade dos grupos sociais, encontra-se implicada, em termos analíticos, a questão da demarcação das fronteiras simbólicas em relação a outros grupos ou identidades socais. Deve-se, portanto, levar em conta o lugar de relevância que ocupa a instância familiar na organização dos grupos sociais em geral (Durham, 1983) e, em particular, na constituição das identidades em grupos populares (Duarte, 1987:215).

Ao descreveram as imagens, os profissionais elegem, num espectro de possibilidades, questões que se referem às suas experiências e relativas aos atendimentos junto à clientela, às experiências de natureza subjetiva e ligadas à esfera pessoal deixando entrever sua percepção acerca dos eventos e comportamentos sexuais e reprodutivos. Essas experiências parecem se constituir, em última instância, em medida de avaliação das imagens produzidas. Pode-se, assim, identificar, como recorrente na narrativa dos profissionais, um tipo de interpretação sobre as imagens produzidas que se caracteriza por sua relação entre as situações encenadas e a realidade, deixando entrever a maneira como concebem a chamada vida real. Dessa maneira, revelam al mejar uma fidelidade das situações representadas à realidade manifestada por meio da crítica aos comportamentos dos personagens e das diversas situações apresentadas, notadamente quanto: ao contexto da situação encenada, ao grau de informação dos personagens sobre os temas de saúde e aos estereótipos e tipos femininos e masculinos representados.

"Eu achei interessante équejustamente os argumentos são as várias - facetas da própria realidade, da própria vida. Então, eles trabaIham com as diversas possibilidades porque, de repente, você pode até... A gente critica achando queela tá bem informadinha, mas você, em determinado momento, pode ter uma menina com muita informação, uma outra que não tenha tanta, a grande maioria e tal. Então, eu acho quejogar com esta multiplicidadedeopções e possi bil idades é o que éo interessante do vídeo, né, e as informações que el etambém vai passando."
“Eu achei também interessantefoi o fato de quequando eu comecei a ver eu disse: 'Ah,não! Esse vídeo tá muito... tá muito fácil, tá muito óbvio, eu acho queeu não vou gostar dele'. (...) E cada vez quevocêachava: 'Não! Isso aí também é impossível', aí mudava. Aí te dava essas outras versões. Outros ângulos. Quando você achava: ‘Não, esseadol escente está muito certinho, muito orientado, muito informadinho...', quando vocêachava que era isso: 'Não, esse vídeo não tá legal, não é a realidade', aí el e muda."

No discurso dos profissionais, as construções do masculino e do feminino são tomados como elementos de referência na descrição das imagens por meio dos personagens. No que concerne à dimensão reprodutiva do corpo, na representação do masculino e do feminino, relacionada à temática gravidez na adolescência, pode-se ver destacada a já reconhecida interioridade feminina em oposição à exterioridade masculina, em face das questões reprodutivas, conforme o segmento:

“Eu acho que foi reflexo da realidade sim. Historicamente o homem fica numa posição muito cômoda, né? E que prá ela não incomoda tanto pensar, o que ele [o vídeo] coloca, a história da barriga mesmo. Já a mulher, tendo ou não acesso aos serviços, ela tem uma preocupação de não engravidar... não digo nem em rel ação à DSTs ou AIDS, não. Mas a gravidez é uma coi sa muito concreta e muito imediata; então eu acho que [o vídeo] reflete nesse sentido sim."

Observou-se, em uma das interações, uma percepção de que as meninas, quando comparadas aos meninos, apresentam-se mais bem informadas sobre assuntos sexuais e reprodutivos. Em relação aos rapazes, foi perceptível uma certa recusa quanto aos tipos representados e um certo mal-estar mediante a representação do comportamento de um adolescente em uma situação específica de aborto.

“Porque é aquela hi stória, se a gente quer chamar o homem prá discussão, construir uma relação nova, não é? Porque é que tem que só reforçar os estereótipos? Claro que, por um lado, (...) reforçando os estereótipos, (...) na discussão, você vai pontuar... Mas, ali [referindose ao vídeo] eu acho que, principal mente para adol escente, já tem que começar a acontecer a quebra desse estereótipo, como aconteceu lá no outro vídeo, né?"

"Mas eu foco muito o comportamento do meni no queo tempo todo não teve a menor reflexão. Derepente, se ele tivesseti do uma reflexão, uma sensibilização, essa coisa do aborto fluía até de outra forma, se tivesse um envolvimento dele." 
Várias tentativas foram feitas a fim de discernir os elementos geradores de mal-estar na produção das imagens sobre uma situação específica de aborto. Nas tentativas de elucidação das causas do desconforto gerado pelas imagens, foram apontados o comportamento masculino, o tema aborto, a caracterização do atendimento médico etc. A referência à família ganhou ênfase pela ausência dessa representação na abordagem desse tema. No entanto, a questão não parece se reduzir a uma definição de conteúdo ou do tema abordado. As explicações oscilam, além das representações referidas ao gênero, entre a forma de abordagem e sua adequação para o público-alvo - o adolescente -, conforme verificado na seguinte seqüência discursiva:

"A imagem é pesada, mesmo."

“E eu não sei nem se é o tema aborto, porque, por exemplo, o vídeo do Jabaquara éaborto também. E eu gosto, é um vídeo que eu gosto de assistir, entendeu?"

"Se é vinculado ao tema. Eu acho que pro (sic) público-alvo, que éadol escente, o tema de veria ser veiculado deuma forma, não sei de alguma outra forma mais leve, né? Poderia ser, de repente, até uma história parecida, mas, sei lá, osprofissionais poderiam ter outro tipo de conduta, né? Não sei."

“É,porqueeu já vi um vídeo, não melembro qual, quetinha situação de aborto, mas era de outra forma, abortava, mas... não ficava essa coisa pesada como você fala, né? (pausa) Agora, realmente, o menino me..."

“É, eu senti falta da família ali. Eu senti falta da família nesse vídeo. A família estaria..., em algum momento teria queter família."

"Pelo tipo de meni na que está se delineando, pelo perfil dela, a família iria perceber, a escola. Tá descontextualizado nesse senti do, porque ela passa..."

A família, como um dos temas clássicos dos estudos antropológicos, tem sido recorrentemente considerada, nas análises, como uma instituição fundamental de socialização, que agrega valor nas diversas posições ocupadas pelos sujeitos na estrutura social - o que parece ser um consenso entre os autores. No entanto, as discordâncias a respeito do tema parecem mais numerosas e parecem agregar-se em torno das mudanças e transformações da família na atual sociedade moderna (Durham, 1983; Salem, 1985; Da Matta, 1987; Figueira, 1987; VeIho, 1987). Logo, na ótica dos profissionais, as situações vivenciadas pelos personagens parecem representadas fora de contexto. Uma questão importante ainda a ser destacada relaciona-se ao papel de mediador do profissional na utilização do vídeo e sua percepção sobre o caráter complementar desse recurso no contexto das práticas educativas, conforme expresso nos fragmentos abaixo:

“Mas eu, particularmente, acho queisso não é o mais... não é o fundamental, porque isso vocêpode tirar de quem está assi stindo."

"Poisé, mas aí éque entra o papel do coordenador. Eu acho pesado esse vídeo pra estar trabalhando com adolescente."

"Eu acho que, por exemplo, poderia se discutir esse vídeo com a família, quer di zer, a família tá ausente, cadê a família? Quer dizer, a própria falta da família ali poderia ser uma questão pro (sic) público, né? Aonde está a família? Que não apareceu nessa história aqui. Já que em algum momento el a deveria entrar."

Deve-se atentar, aqui, para o fato de que o lugar ocupado pelo coordenador encontra-se definido por uma determinada posição que ele tem no cenário institucional. Suas ações encontram-se determinadas por diversas racionalidades, sejam elas técnicas e políticas informadas pelas instâncias governamentais, ou mesmo por movimentos sociais que alcançam a rede de serviços. Essa heterogeneidade coloca, em última instância, grandes contradições para os atores envolvidos nas ações que interagem no cenário do setor saúde. Uma delas diz respeito a possíveis dissociações entre as orientações dirigi das à clientela em termos do comportamento preventivo e as condutas e atitudes pessoais e subjetivas do próprio coordenador, geradoras de conflitos, em particular quanto ao uso de métodos contraceptivos e preservativos com vistas à prevenção da AIDS.

“Mas, por exemplo, assim, em relação ao uso da cami sinha: eu não uso camisinha, como deveria ser usado, masaí...(...) Eu não uso, maseu não estou jogando a culpa nas costas de ninguém (...) enem quero deixar defal ar queé importante,entendeu?"

“(...) Eu fiz ligadura, não mearrependo, eeu sei que há toda uma pressão, todo um discurso no senti do contrário, entendeu? Eu nunca me senti cômoda para trabalhar no planejamento familiar. (...) A mim incomoda. Eu não vejo isso como uma coisa pessoal aqui da gente não. É que levanta contradições, que, digamosassim, chegam a mesufocar."

“(...) E eu acho queé mais ou menos isso: a gente acaba muitas vezes repetindo algumas coisas que ouve, milhões de discursos que são consi derados teori camente corretos e que você não dá uma parada, entendeu? Pra sacudir e ver profundamenteo queé."

Assim, pode-se reconhecer a importância do papel mediador do coordenador nos pro- 
cessos educativos comunicativos. Faz-se necessário, ainda, relativizar as explicações do sentir e agir humanos, referidos ao gênero e ao sexo, a fim de possibilitar uma compreensão da experiência sexual que recoloque o discurso do sujeito como pólo de significação. Acredita-se que esse caminho possa revelar outros ângulos distintos daqueles socialmente instituídos e legitimados. Isso está colocado genericamente como questão para toda a ação educativa preventiva, mas parece ser ainda mais complexo em se tratando da abordagem da sexualidade nesse campo. Finalmente, não se pretendeu abarcar a multiplicidade de aspectos passíveis de análise, nem tampouco oferecer respostas conclusivas. Nossa intenção consistiu em indicar a necessidade de que sejam consideradas, nas ações e produções de materiais, as concepções do corpo e da sexualidade como mediações culturais determinantes do processo educativo comunicativo, modeladores da subjetividade e da percepção dos sujeitos em variados contextos.

\section{Considerações finais}

Pode-se dizer que os vídeos educativos, identificados como um recurso para a reflexão, potencialmente promovem uma identificação e sensibilização do público para os temas de saúde. No entanto, eles podem estar cumprindo, em primeira instância, uma função de ilustração dos discursos que informam as práticas no campo da saúde na atualidade, colocandose à parte na exploração do imaginário social que perpassa de forma diferenciada o comportamento preventivo dos sujeitos pertencentes a grupos culturalmente definidos. Não se pode determinar como ocorre a recepção das mensagens para o chamado segmento popular, pois encontra seus limites de compreensão dessas questões na delimitação do objeto dessa investigação. Portanto, sugere-se a realização de ou- tros estudos que contemplem a recepção das mensagens pelos diversos grupos aos quais as estas são destinadas. Acreditamos que a compreensão das lógicas que regem os discursos sobre o corpo ganha importância à medida que oferece um caminho de questionamento dos estreitos limites de uma visão normativa da sexualidade que, engendrada nos meandros do tecido social, desafia os processos de comunicação voltados à intervenção educativa. Sua relevância também reside no atravessamento dessas concepções por práticas sociais desenvolvidas em diferentes contextos, envolvendo ao mesmo tempo realizadores, produtores e receptores das mensagens educativas. Cumpre, assim, buscar a atribuição do significado pelos sujeitos sociais que se constituem singularmente através do olhar que lançam sobre os discursos que Ihes são ofertados e pelas ações intervencionistas que recaem sobre seu corpo.

Ao refletir-se sobre as práticas educativas e de comunicação no campo da saúde, emergentes num mundo onde a diferença se apresenta como ameaça e não como abertura ao novo, pode-se reconhecer que as possibilidades de mudança do ângulo de visão sobre os fenômenos que acometem o corpo humano encontram-se restritas. A abertura e a possibilidade de construção de novos olhares de ruptura de um saber racional, seja ele qual for - até mesmos os mais progressistas - , que fala pelos outros, encontram-se na maneira como aprendemos e ensinamos a ser sujeitos e como construímos e descrevemos as imagens do outro, por meio das formas discursivas emergentes no cotidiano, ou dos discursos materializados em imagens. Com isso, pretendemos, fundamentalmente, tentar iluminar a nossa forma de ver, perceber e reconceber práticas comunicativas e determinados processos estruturadores da prática social que tradicionalmente tem sido cenário de intervenções disciplinadoras sobre vida, sexualidade e morte.

\section{Referências}

ABRASCO (Associação Brasileira de Saúde Coletiva), 1992. Comunicação Social em Saúde: Diagnóstico Preliminar das Práticas Institucionais na Saúdee Contribuições para o Delineamento deuma Política. Rio de Janeiro: Abrasco.

AUM ONT, J., 1993. A Imagem. Campinas: Papirus.

ASSIS, M., 1992. Da Hipertensão à Vida: Por uma Práxis Comunicativa na Educação eSaúde. Dissertação de Mestrado, Rio de Janeiro: Instituto de Medicina Preventiva e Social, Universidade do Estado do Rio de Janeiro. 
BARBERO, M., 1995. América Latina e os anos recentes: O estudo da recepção em comuni cação social. In: Sujeito, o Lado Oculto do Receptor (M. W. Souza, org.), pp. 39-68, São Paulo: Brasiliense/ ECA/ Universidade de São Paulo.

BARBOSA, R. \& VILLELA, W. V., 1994. A trajetória feminina da AIDS. In: Seminário Mulher e Cidadania: Rumos e Descaminhos das Políticas Sociais, Resumos, pp. 18. Associação Brasileira de Estudos de População.

BOLTANSKI, L., 1979. As Classes Sociais e o Corpo. Rio deJaneiro: Edições Graal

BORGES, S. N. 1996. Metamorfoses do Corpo: Uma Pe dagogia Freudiana. Rio de Janeiro: Editora Fiocruz.

BOURDIEU, P., 1995. A dominação masculina. Educação e Realidade, 20:133-184.

CHATEL, M., 1995. Mal-estar na Procriação: As MuIheres ea Medicina da Reprodução. Rio de Janeiro: Campo Matêmico.

CECCON, C. S. P., 1989. A criação coletiva. Revista Proposta - Experiências em Educação Popular, 43:26-31.

COSTA, J. F., 1996. O referente da identidade homossexual. In: Sexual idades Brasileiras (R. Parker \& R. M. Barbosa, org.), pp. 63-89, Rio de Janeiro: Editora Relume-Dumará/Associação Brasileira Interdisciplinar de AIDS/Instituto de Medicina Social, Universidade do Estado do Rio de Janeiro.

DA M ATTA, R., 1987. A família como valor: Considerações não-familiares sobre a família à brasileira. In: Pensando a Família no Brasil - Da Colônia à Modernidade (A. M. Almeida, J. M. Carneiro \& S. G. Paula, org.), pp. 115-136, Rio de Janeiro: Espaço e Tempo/Universidade Federal do Rio de Janeiro.

DESLANDES, S. F., 1997. Concepções em pesquisa social: Articulações com o campo da avaliação em serviços de saúde. Cadernos de Saúde Pública, 13:103-107.

DUARTE, L. F. D., 1986. Da Vida Nervosa nas Classes Trabal hadoras Urbanas. Rio de Janeiro: Jorge Zahar/Consel ho Nacional de Desenvolvimento $\mathrm{Ci}$ entífico e Tecnológico - CNPq.

DUARTE, L. F. D., 1987. Pouca vergonha, muita vergonha: Sexo e moralidade entre as classes trabaIhadoras urbanas. In: Cultura eldentidade Operária. Aspectos da Cultura da Classe Trabalhadora (J. S. L. Lopes, org.), pp. 203-226, Rio de Janeiro: Universidade Federal do Rio de Janeiro/Editora Marco Zero.

DUARTE, L. F. D. \& LEAL, O., 1998. Doença, Perturbação e Sofrimento: Perspectivas Etnográficas. Rio deJaneiro: Editora Fiocruz.

FASE, 1989. A comunicação como mediadora do conhecimento. Revista Proposta - Experiências em Educação Popular, 43:11-21.

DURHAM, E. R., 1983. Família e reprodução humana. In: Perspectivas Antropológicas da Mulher (B. Franchetto, M. L. V. C. Cavalcanti \& M. L. Heilborn, org.), pp. 13-44, Rio de Janeiro: Zahar.

FIGUEIRA, S., 1986. O ‘moderno' e o 'arcaico' na nova família brasileira: notas sobre a dimensão invisível da mudança social. In: Uma nova Família? O Moderno eo Arcaico na Família de Classe Média Brasileira (S. Figueira, ed.), pp. 11-30, Rio de Janeiro: Zahar.
GUIMARÃES, C. D., 1994a. Mulheres, sexualidade e AIDS: Um projeto de prevenção. In: Alternativas Escassas: Saúde, Sexualidade e Reprodução da América Latina (A. O. Costa \& T. Amado, org.), pp. 249-281, Rio de Janeiro: Editora 34.

GUIM ARÃES, C. D., 1994b. Mulheres, homens e AIDS: O visível e o invisível. In: A AIDS no Brasil - História Social da AIDS (R. Parker \& R. M. Barbosa, org.), pp. 217-230, Rio de Janeiro: Editora Relume-Dumará.

GUIMARÃES, C. D., 1996. Questões ocultas: A percepção dos riscos da AIDS na ótica de gênero. In: XX Encontro ANPOCS - Grupo de Trabalho: Relações de Gênero. Caxambu: Associação Nacional de Pós-graduação em Ciências Sociais - ANPOCS. (mimeo.)

HEILBORN, M. L., 1993. Gênero e hierarquia: A costela de Adão revisitada. Estudos Feministas, 1:50-82.

HEI LBORN, M. L., 1994. De que gênero estamos falando? Sexualidade, Gênero e Soci edade, 2:6-8.

HEILBORN, M. L., 1996. Ser ou estar homossexual: Dilemas de construção de identidade social. In: Sexual idades Brasileiras (R. Parker \& R. M. Barbosa, org.), pp. 136-145, Rio de Janeiro: Editora Relume-Dumará.

HEILBORN, M. L., 1998. Gênero, um olhar estruturalista. In: Masculino, Feminino, Plural (J. M. Pedro \& M. P. Grossi, org.), pp. 43-55, Florianópolis: Editora Mulheres.

HEILBORN, M. L. \& GOUVEIA, P. F., 1997. Classes trabalhadoras, mulheres e sexual idade no contexto da AIDS. In: II Seminário Saúde Reprodutiva em Tempos de AIDS, ABIA e Programa de Estudos e Pesquisa em Gênero, Sexuali dade e Saúde - IMS/ UERJ (J. Galvão, org.), pp. 43-54, Rio de Janeiro: Editora Relume-Dumará.

HÉRITIER, F., 1978. Fécondité et stérilité: La traduction de ces notions dans le champ idéologique au stade préscientifique. In: Le Fait Féminin ( $E$. Sullerot, org.), pp. 387-396, Paris: Fayard.

HOLLANDA, E., 1993. Práticas alternativas de pesquisa: Alguns questionamentos sobre as potencialidades e limites da pesquisa-ação e pesquisa participante. In: Partici pação Popular, Educação e Saúde: Teoria e Prática (V. Valla \&E. N. Stotz, org.), pp. 23-51, Rio de Janeiro: Editora Relume-Dumará.

ISER, W., 1979. A interação do leitor com o texto. In: A Literatura e o Leitor - Textos de Estética da Recepção (L. Lima, coord.), pp. 83-132, Rio de Janeiro: Paz eTerra.

KNAUTH, D. R., 1995. Um problema de família: A percepção da AIDS entre mulheres soropositivas. In: Corpo e Significado: Ensaios de Antropol ogi a Social (O. F. Leal, org.), pp. 379-390, Porto Alegre: Editora da Universidade Federal do Rio Grande do Sul.

KNAUTH, D. R., 1996. AIDS, Rel ações de Consangüinidadee de Aliança. Texto apresentado no XX Encontro Anual da ANPOCS. Caxambu: Associação Nacional de Pós-graduação em Ciências Sociais ANPOCS.

KNAUTH, D. R., 1998. Morte masculina: Homens portadores do vírus da AIDS sob a perspectiva feminina. In: Doença,Sofrimento, Perturbação: Perspectivas Etnográficas (O. F. Leal \& L. F. Duarte, org.), pp. 183-198, Rio de Janeiro: Editora Fiocruz. 
LEAL, O. F., 1995a. Corpo e Significado: Ensai os de Antropologia Social. Porto Alegre: Editora da Universidade Federal do Rio Grande do Sul.

LEAL, O. F., 1995b. Etnografia de audiência: Uma discussão metodológica. In: Sujeito, o Lado Oculto do Receptor (M. W. Souza, org.), pp. 113-121, São Paulo: Editora Brasiliense/ Escola de Comunicação e Artes/Universidade de São Paulo.

LEFĖVRE, F., 1995. Saúde, Doença e Relação de Consumo. Material da Disciplina Comuni cação em Saúde. Dissertação de Mestrado, Rio de Janeiro: Núcleo de Tecnologia Educacional para a Saúde, Universidade Federal do Rio de Janeiro.

LOPES, M. I. V., 1994. Pesquisa em Comuni cação: Formulação de um Modelo Metodológico. São Paulo: Editora Loyola.

LOYOLA, M. A, 1992. Sexualidade e reprodução. Physis - Revista de SaúdeColetiva, 2:93-104.

MACHADO, A., 1996. Máquina e Imaginário: O De safio das Poéticas Tecnológicas. São Paulo: Edusp.

MELO, J. A., 1993. Educação: Razão e Paixão. Rio de Janeiro: Escola Nacional de Saúde Pública.

MELO, J. M., 1985. Comunicação: Teoria e Política. São Paulo: Summus.

MELO, J. V., 1993. Trabal ho de Formiga em Terra de Tamanduá - A Experiência Feminista com Vídeo. Dissertação de Mestrado, São Paulo: Escola de Comunicação e Artes/Universidade de São Paulo.

MONTEIRO, S., 1999. AIDS, Sexualidade e Gênero: A lógica da Proteção entre Jovens em um Bairro Popular Carioca. Tese de Doutorado, Rio de Janeiro: Escola Nacional de Saúde Pública, Fundação Oswaldo Cruz.

MONTEIRO, S.; REBELLO, S. \& SCHALL, V., 1994. Jogando e aprendendo a viver: Uma abordagem da AIDS e das drogas através de recursos educativos. In: Drogas e AIDS - Estratégi as de Redução de Danos (F. Mesquita \& F. Bastos, org.), pp. 133-146, São Paulo: Editora Hucitec.

MS (Ministério da Saúde), 1983. Assistência Integral à Saúde da Mulher: Bases para uma Prática Educativa. Brasília: MS/ PAISM (Programa de Assistência Integral à Saúde da Mulher).

NETO, A. F., 1995. A deflagração do sentido. Estratégias de produção e de captura da recepção. In: Sujeito, o Lado Ocul to do Receptor (M. W. Souza, org.), pp. 189-222, São Paulo: Brasiliense/ Escola de Comunicação e Artes/Universidade de São Paulo.

OROZCO, G. \&JACKS, N., 1993. Pesquisa de recepção: Investigadores, paradigmas, contribuições latino-americanas. Revista Brasileira de Comunicação, 16:22-33.

OSHIRO, J., 1988. Educação para Saúde nas Instituições de Saúde Pública. Dissertação de Mestrado, São Paulo: Pontifícia Universidade Católica.

PAM PLONA, V. L., 1990. Mulher, Parto e Psicodrama. São Paulo: Ágora.

PAULA, S., 1996. Produção Cultural e Ação Política: O Uso do Vídeo como Processo de Recriação Étnica. Texto apresentado no XX Encontro Anual da ANPOCS. Caxambu: Associação Nacional de Pós-graduação em Ciências Sociais - AN POCS. (mimeo.)

PEREIRA, G. S., 1993. O Profissional de Saúdee a Educação em Saúde: Representações de uma Prática. Dissertação de Mestrado, Rio de Janeiro: Escola
Nacional de Saúde Pública, Fundação Oswaldo Cruz.

PITTA, A. M. \& MEIRA, R., 1990. Comunicação social em saúde e modelo assistencial. Do discurso médico hegemônico ao discurso da integralidade Uma introdução à discussão de modelos. Saúde em Debate, 32:84-92.

ROM ANO, M. C. J. S., 1990. O que Pinta de Novo na Tela do Povo. Dissertação de Mestrado, Niterói: Faculdade de Educação, Universidade Federal Fluminense

ROPA, D. \& DUARTE, L. F. D., 1985. Considerações teóricas sobre a questão do "aten dimento psicológico" às classes trabalhadoras. In: Cultura da Psicanálise (S. Figueira, org.), pp. 178-201, São Paulo: Editora Brasiliense.

ROZEMBERG, B., 1995a. Projeto de avaliação do vídeo educativo Doença do Caramujo na mobilização de debates sobre o controle da esquistossomose. Rio de Janeiro: TDR/UNDP/World Bank/WHO. (mimeo.)

ROZEMBERG, B., 1995b. A Intransparência da Comunicação: Crítica Teórico-Metodológica sobre a Interação do Saber e das Práticas Médicas e a Experiência da População de Área Rural Endêmica de Esquistossomose Tese de doutorado, Rio de Janeiro: Escola Nacional de Saúde Pública, Fundação Oswaldo Cruz.

SALEM , T., 1985. Família em camadas médias: Uma revisão da literatura recente. Bol etim do Museu Nacional, 54:1-29.

SCHALL, T.V. \& STRUCHINER, M., 1995. Educação no contexto da epidemia de HIV/AIDS: teorias e tendências pedagógicas. In: AIDS - Pesquisa Social e Educação (D. Czeresnia, E. M. Santos, R. H. S. Barbosa \& S. Monteeiro, org.), pp. 84-105, São Paulo: Editora Hucitec/ Rio de Janeiro: Abrasco.

SILVER, L., 1992. Aspectos metodológicos em avaliação dos serviços de saúde. In: Planejamento Criativo (E. Gallo, F. J. Rivera \& M. H. Machado, org.), pp. 195-210, Rio de Janeiro: Editora Relume-Dumará.

SIQUEIRA, V. H. F., 1998. O vídeo educativo produzido pelo Núcleo de Tecnologia Educacional para a Saúde/UFRJ: Uma visão crítica. Revista Brasileira deEducação Médica, 22:77-82.

VALLA, V. \& STOTZ, E. N., 1993. Participação Popular, Educação e Saúde: Teoria e Prática. Rio de Janeiro: Editora Relume-Dumará

VARGAS, E. P., 1998. Corpo e Sexualidadeatravés das Imagensem Vídeo. Dissertação de Mestrado, Rio de Janeiro: Núcleo de Tecnologia Educacional para a Saúde, Universidade Federal do Rio de Janeiro.

VELHO, G., 1987. Família e subjetividade. In: Pensando a Família no Brasil - Da Colônia à Modernidade (A. M. Almeida, J. M. Carneiro \& S. G. Paula, org.), pp. 79-87, Rio de Janeiro: Editora Espaço eTempo/Universidade Federal do Rio de Janeiro.

VIEIRA, E. M., 1990. Prática Médica e Corpo Feminino. Dissertação de Mestrado, São Paulo: Departamento de Medicina Preventiva da Faculdade de Medicina, Universidade de São Paulo. 